Vol. 2 | No. 2 | 2021 | Hal. 124-129

\title{
PENGEMBANGAN MINAT BACA UNTUK MENINGKATKAN BUDAYA LITERASI SISWA SEKOLAH
}

\author{
Bagus Cahyanto*, Mar'atul Hasanatin, Imasatul Adamiyah, Heni Risky Amalia, \\ Safiratul Janah, Anggraini Nur Dianti, Adilah Salsabilah Mukhtar, Cusnul May Syaroh, \\ Titik Nur Latifah, Khotimatul Mardiyah, Fitriyati \\ Fakultas Agama Islam, Universitas Islam Malang \\ *korespondensi email: cahyanto@unisma.ac.id
}

\begin{abstract}
ABSTRAK
Pembatasan kegiatan masyarakat di masa pandemic Covid-19 menyebabkan sekolah diselenggarakan secara online, tak terkecuali diterapkan di Kebalen Wetan Gang Mawar. Sekolah daring berarti anak-anak menggunakan gawai untuk mengikuti pembelajaran yang berdampak pada peningkatan penggunaan gawai pada anak-anak terutama di tingkat sekolah dasar. Dibatasinya aktivitas anak-anak di luar rumah juga mengharuskan anak-anak berada di rumah sepajang hari. Karakteristik anak usia sekolah dasar yang aktif menjadi salah satu faktor jika anak-anak akan mudah merasa bosan bermain sendiri di rumah. Tak jarang orang tua memberikan gawai agar anaknya bisa diam di rumah, dan hal itu cukup menyita perhatian anak dengan adanya beragam aplikasi menarik dalam gawai. Sementara di Kebalen Wetan Gang Mawar anak-anak terkadang bermain di luar dengan teman sebayanya untuk mengatasi rasa bosan dan tak bisa dihindari bahwa mereka bisa saja melalaikan protocol kesehatan apalagi jika tanpa pantauan orang dewasa. Maka dengan dilakukannya kegiatan untuk menumbuhkan budaya literasi membaca dan menulis menjadi alternative kegiatan yang lebih bermanfaat untuk anak-anak. Budaya literasi dapat meningkatkan kualitas pendidikan di Indonesia terutama jika mulai diterapkan sejak dini, dan di tingkat sekolah dasar dimana anak-anak berada pada masa emas adalah waktu yang tepat untuk memulai. Metode pelaksanaan kegiatan menumbuhkan budaya literasi ini yaitu pendidikan masyarakat. Penumbuhan budaya literasi melalui peningkatan minat baca ini dilakukan pada anak-anak tingkat sekolah di Kebalen Wetan Gang Mawar selama masa pelaksanaan KSM-Tematik. Berdasarkan data yang didapat dari hasil evaluasi dengan jumlah literasi yang dilakukan anak-anak selama satu minggu menunjukkan pertumbuhan budaya literasi dari mereka yang sebelumnya belum pernah melakukannya. Tujuan dalam penumbuhan budaya literasi di kalangan anak-anak tingkat sekolah dasar di Kebalen Wetan Gang Mawar yaitu mencetak generasi muda yang berintelektual. Kegiatan literasi membaca dapat menambah kosakata bahasa anak sekaligus memperluas wawasan mereka. Sementara kegiatan literasi menulis dapat meningkatkan kreatifitas anak yang tertuang dalam tulisan mereka, baik menulis ulang cerita dari buku yang sudah mereka baca dengan bahasa sendiri maupun menulis cerita dengan ide mereka sendiri.
\end{abstract}

Kata Kunci: budaya; literasi; membaca

\section{PENDAHULUAN}

Kebalen Wetan merupakan salah satu wilayah yang terletak di tengah Kota Malang. Daerah ini menjadi bagian dari Kecamatan Kedungkandang tepatnya di Kelurahan Kotalama. 
Setiap kanan dan kiri ruas jalannya mudah ditemukan ruko dan toko berjerjer serta terdapat Pasar Kebalen sehingga jalanannya biasanya sangat ramai dan tak jarang mengakibatkan kemacetan. Penduduknya mayoritas bekerja sebagai pedagang. Letaknya strategis dan mudah djangkau dengan berbagai sarana transportasi angkutan umum seperti mikrolet, bus dan kereta api. Stasiun kereta api terdekat yaitu Stasiun Kota Lama yang dapat ditempuh sekitar 10 menit, sementara Stasiun Kota Baru dapat ditempuh sekitar 7 menit. Ramainya Kebalen Wetan termasuk selain karena sebagai salah satu pusat perbelanjaan yaitu karena daerah ini dekat dengan salah satu tempat wisata yang terkenal di Kota Malang, yaitu Kampung Wisata Warna-Warni di Jodipan. Biaya tiket masuk yang murah dan terdapat banyaknya spot foto instagramable yang digemari oleh banyak anak muda menjadi daya tarik yang kuat sebagai salah satu tempat wisata di Kota Malang yang harus dikunjungi.

Kebalen Wetan termasuk kawasan dengan pemukiman yang cukup padat. Pelaksanaan pembatasan kegiatan masyarakat di masa pandemic juga berlaku di daerah ini. Seperti terdapatnya posko PPKM serta adanya kran cuci tangan di tempat-tempat yang banyak dikunjungi. Pembatasan kegiatan tersebut berlaku bagi seluruh masyarakat dari anak-anak sampai dewasa. Sekolah diselenggarakan secara online mengharuskan anak-anak menghabiskan seluruh waktunya di rumah. Tingkat penggunaan gawai pada anak-anak juga menjadi bertambah, selain digunakan untuk kepentingan sekolah secara daring, banyak dari mereka yang menggunakannya untuk mengatasi rasa bosan.

Berdasarkan karakteristik anak-anak tingkat sekolah dasar usia 6-12 tahun, mereka lebih senang bermain, senang bergerak, senang bekerja dalam kelompok, dan senang merasakan atau melakukan sesuatu secara langsung (Desmita, 2010; Rahmawati \& Tutiasri, 2021). Namun dengan adanya aturan pembatasan kegiatan anak-anak mau tidak mau menghabiskan waktu di rumah setelah jam sekolah daring selesai. tak sedikit orang tua yang membelikan gawai pribadi untuk anaknya agar mereka tidak merasa bosan di rumah. Di Kebalen Wetan Gang Mawar RT 09 RW 04 dimana penulis melaksanakan KSM-Tematik, para orang tua dari anak-anak tingkat sekolah dasar memberikan gawai hanya untuk kepentingan sekolah. Setelah waktu sekolah selesai biasanya anak-anak akan keluar bermain bersama teman sebayanya. Karakteristik anak-anak usia sekolah dasar yang sangat aktif adalah salah satu faktor lalainya mereka menaati protocol kesehatan Covid-19 ketika sedang bermain. Sebab itulah penulis ingin menumbuhkan budaya literasi di kalangan anak-anak Kebalen Wetan Gang Mawar sebagai salah satu alternative kegiatan untuk mengatasi rasa bosan di masa pandemic agar tidak terlalu sering keluar dari rumah.

Faktor lainnya yang tak kalah penting yaitu dalam konteks pendidikan, literasi sebagai salah satu solusi untuk mengatasi terpuruknya kualitas pendidikan di tanah air yang dianggap belum menjawab masalah karakter bangsa (Kurniasih et al., 2019). Permendikbud no 23 tahun 2015 tentang Penumbuhan Budi Pekerti dengan tegas menyebutkan pentingnya pembiasaan 15 menit membaca setiap hari. Untuk memberikan panduan implementasinya di lapangan, Direktorat Pendidikan Dasar dan Menengah Kemdikbud telah menerbitkan seperangkat dokumen, yakni Disain Induk Gerakan Literasi Sekolah (GLS), Buku Saku GLS, dan Panduan GLS untuk setiap jenjang pendidikan (Hidayah, 2017).

Pentingnya budaya literasi terutama untuk anak-anak usia sekolah dasar dimana mereka berada pada masa golden age. Literasi merupakan kemampuan awal yang harus dimiliki setiap individu untuk menjalani kehidupan dimasa depan. Pembelajaran literasi akan mendapat hasil optimal apabila diberikan sejak anak usia dini sehingga disebut literasi awal. Hal ini dikarenakan pada usia dini tejadi masa golden age, yaitu masa keemasan anak dimana masa itu anak mengalami masa perkembangan yang sangat pesat dan masa golden ini terjadi pada masa prasekolah (Uce, 2015). Masa anak merupakan masa emas (The Golden Age) bagi penyelenggaraan pendidikan termasuk pada aspek penanaman budaya literasi. Masa 
anak merupakan fase/tahap yang sangat fundamental bagi perkembangan individu karena pada fase/tahap inilah terjadinya peluang yang cukup besar untuk pembentukan dan pengembangan pribadi seseorang (Masdudi, 2015).

Menurut tahap Piaget, masa sekolah dasar berada pada tahap concrete operational. The concrate operational stage is characterized by remarkable cognitive growth and is a formative one in schooling, because its when children's language and basic skill acquisition accelerate dramatically (Ojose, 2008). Pernyataan tersebut berarti bahwa pada tahap operasional konkret ditandai dengan pertumbuhan kognitif yang luar biasa dan merupakan tahap formatif dalam pendidikan sekolah, karena ini masanya penguasaan bahasa dan keterampilan-keterampilan dasar anak berkembang cepat secara dramatis (Dewi, 2019). Menumbuhan budaya literasi melalui peningkatan minat baca merupakan salah satu cara menambah kosakata bahasa anak-anak pada usia sekolah dasar.

Kegiatan literasi yang dilakukan dalam konteks ini yaitu membaca dan menulis. Maka untuk menumbuhkan budaya itu penulis berupaya meningkatkan minat baca pada anakanak dengan pengenalan budaya membaca buku. Meningkatnya minat baca anak bisa memacu anak untuk terus membaca dan bisa tersalurkan dengan menulis; menulis dari cerita yang sudah mereka baca lalu diceritakan dengan bahasa mereka sendiri maupun menulis cerita dengan ide mereka. Penumbuhan budaya membaca melalui peningkatan minat baca ini bertujuan mewujudkan generasi muda yang kreatif dan berintelektual dengan pengetahuan dan wawasan yang luas. Kegiatan literasi ini juga dapat meningkatkan konsentrasi anak serta menjadi alternative kegiatan yang lebih bermanfaat untuk mengusir rasa bosan anak di rumah.

\section{METODE}

Metode yang digunakan penulis untuk menumbuhkan budaya literasi melalui pendampingan pengembangan minat baca kepada masyarakat. Pelaksanakaan tahapantahapan dalam metode dilaksanakan dalam periode waktu pelaksanaan KSM-Tematik selama satu bulan. Subjeknya adalah anak-anak tingkat sekolah dasar kelas 1-6 di Kebalen Wetan Gang Mawar RT 09 RW 04.

Pada pekan pertama pelaksanaan, peserta KSM-Tematik melakukan program sekaligus membuka donasi buku untuk menambah bahan referensi dan pembuatan sudut baca lemari Al-Amin di kawasan Kota Malang melalui pamflet yang disebarkan di media sosial dan mengenalkan budaya membaca pada anak-anak dengan membagikan buku-buku cerita untuk dibaca. Pada pekan kedua anak-anak menulis cerita pendek dengan bahasa mereka sendiri dari gambar berurutan kemudian dibacakan di depan teman-teman lainnya. Pada pekan ketiga anak-anak diberikan beragam buku cerita untuk dibaca, setelah selesai mereka diminta menceritakan dengan bahasa mereka sendiri di depan teman-teman lainnya. Pada pekan keempat anak-anak melakukan kegiatan literasi membaca dan menulis selama satu minggu.

Evaluasi dari tahapan-tahapan kegiatan tersebut adalah banyaknya catatan literasi yang dibuat masing-masing anak setelah membaca buku dalam kurun waktu satu minggu. Buku-buku yang digunakan oleh anak-anak untuk kegiatan literasi adalah milik lemari baca Al-Amin, buku-buku dari donasi, dan buku-buku dari peserta KSM. Statistic yang digunakan untuk menganalisis data yaitu berupa tabel.

\section{HASIL DAN PEMBAHASAN}

Penumbuhan budaya literasi melalui peningkatan minat baca pada anak-anak tingkat sekolah dasar di Kebalen Wetan Gang Mawar merupakan salah satu program kerja KSMTematik penulis. Dengan meningkatkan minat baca anak-anak melalui tahapan-tahapan 
kegiatan dari program kerja tersebut yang sudah disebutkan pada bagian metode sebelumnya, dapat menumbuhkan budaya literasi pada anak-anak. Data yang diperoleh dari hasil evaluasi kegiatan literasi membaca dan menulis dalam jangka waktu satu minggu disajikan pada tabel di bawah ini.

Tabel 1. Data jumlah literasi

\begin{tabular}{cccc}
\hline Nama & $\begin{array}{c}\text { Pengalaman } \\
\text { literasi }\end{array}$ & Kelas & $\begin{array}{c}\text { Jumlah } \\
\text { pendampingan } \\
\text { program }\end{array}$ \\
\hline Aisyahtul Lutfiah & Belum pernah & 6 & 9 \\
Zahwa Alfadillah & Pernah & 6 & 32 \\
Zida Hilmiatuz Zahro & Belum pernah & 6 & 7 \\
Arina Husna & Pernah & 5 & 29 \\
Lailatul Khoirul Maulidia & Belum pernah & 5 & 7 \\
Ayu Cahya Pratiwi & Belum pernah & 4 & 8 \\
Nabilatun Nisa & pernah & 4 & 14 \\
Naysila Amanda & Belum pernah & 4 & 7 \\
Muhammad Rizki Maulana & Belum pernah & 3 & 5 \\
Zahro Camelia & Belum pernah & 3 & 7 \\
\hline
\end{tabular}

Berdasarkan pada tabel diatas didapatkan hanya 3 orang anak yang pernah melakukan kegiatan literasi membaca dan menulis, sementara 7 lainnya belum pernah. Hal ini menunjukkan bahwa literasi belum menjadi tradisi di sekolah maupun di lingkungan sekitarnya. Maka dapat disimpulkan bahwa budaya literasi membaca dan menulis di kalangan anak-anak tingkat sekolah dasar di Kebalen Wetan Gang Mawar masih cukup baru. Namun setelah melaksanakan kegiatan-kegiatan pelatihan dalam program kerja penumbuhan budaya literasi melalui peningkatan minat baca, menurut pada tabel data jumlah literasi di atas didapatkan hasil bahwa rata-rata dari mereka berupaya menyempatkan waktu untuk membaca dan menulis setiap harinya. Pada kegiatan yang dijadwalkan anak-anak diberikan waktu 15 menit setiap harinya untuk melakukan kegiatan literasi membaca dan menulis sesuai. Melalui kegiatan-kegiatan pelatihan yang dilakukan menunjukkan pertumbuhan budaya literasi karena meningkatnya minat baca anak-anak. Hal tersebut berarti bahwa adanya peningkatan minat baca pada beberapa anak yang sebelumnya belum pernah melakukan kegiatan literasi.

Pertumbuhan budaya literasi tersebut dapat berlanjut menjadi kebiasaan yang berawal dari meningkatnya minat membaca. Beragamnya variasi buku bacaan di lemari baca Al-Amin menjadi salah satu faktor meningkatnya minat membaca anak. Buku cerita seperti novel, buku cerita bergambar, kumpulan cerita pendek, komik, dan sejenisnya merupakan buku yang menarik dibaca untuk anak-anak tingkat sekolah dasar. Penumbuhan budaya literasi dengan membaca buku-buku cerita oleh anak-anak menjadi awal yang baik dalam penanaman budaya membaca karena dapat menambah kosakata bahasa anak di usia mereka serta menambah wawasan yang tertuang dalam kreatifitas tulisan mereka ketika kegiatan literasi menulis. Dengan tumbuhnya budaya membaca dari buku cerita yang menjadi kebiasaan dengan jadwal yang rutin, maka seiring dengan tumbuhnya usia anak dan kebutuhan pengetahuan yang lebih luas mereka dapat terbiasa dengan buku bacaan pengetahuan umum.

Adanya lemari baca Al-Amin di rumah belajar Al-Amin sangat menunjang kegiatan literasi anak-anak dengan beragam buku bacaan yang tersedia. Anak-anak bisa meminjam dengan menuliskan di buku daftar peminjaman buku. Lemari baca Al-Amin memiliki 2 orang anak yang ditunjuk sebagai penanggung jawab. Jika ada keterlambatan pengembalian buku maka mereka bertugas mengingatkan. Mereka juga bertugas untuk merawat buku-buku di 
lemari baca. Dengan dibentuknya penanggung jawab tersebut cukup dapat memotivasi mereka untuk melakukan kegiatan literasi membaca dan menulis.

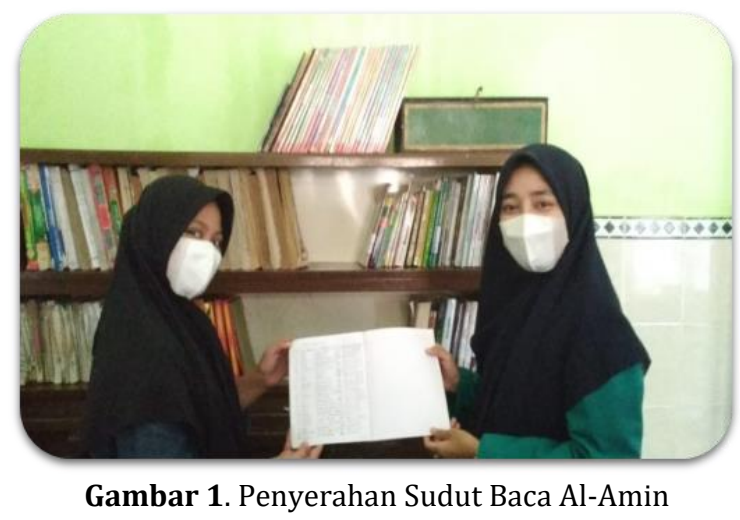

\section{KESIMPULAN}

Tujuan dalam penumbuhan budaya literasi ini tercapai dengan adanya hasil tulisan literasi dari buku yang dibaca anak-anak sebagai bentuk kreatifitas mereka dalam hal menulis dengan bahasa mereka sendiri. Dalam hal intelektual kegiatan literasi membaca menambah kosakata anak-anak yang tersalurkan pada kegiatan literasi menulis. Budaya literasi membaca dan menulis sebagai budaya yang masih baru di kalangan anak-anak tingkat sekolah dasar di Kebalen Wetan Gang Mawar menjadi kegiatan untuk menghabiskan waktu yang lebih bermanfaat bagi anak-anak dengan bertambahnya wawasan mereka terutama di masa pandemic. Rencana tindak lanjut dari program penumbuhan budaya literasi membaca dan menulis ini yaitu dengan membuat jadwal rutin kegiatan literasi di rumah belajar Al-Amin. Anak-anak dapat meluangkan waktu untuk melakukan literasi secara rutin serta dapat menambah motivasi membaca dengan melakukannya bersama teman-teman lainnya. Kegiatan rutin literasi di rumah belajar diharapkan dapat membentuk kebiasaan literasi membaca dan menulis.

\section{UCAPAN TERIMA KASIH}

Ucapan terima kasih kami sampaikan kepada Ketua RT Bapak Suhendro atas bantuannya untuk kami dalam melaksanakan kegiatan KSM-Tematik, tersedianya fasilitas yang memudahkan serta saran dan dukungannya sehingga kami dapat menyelesaikan pengabdian dengan lancar. Terima kasih tak terhingga juga untuk para donator buku sehingga kami dapat mewujudkan pembuatan lemari baca di Rumah Belajar Al-Amin. Terima kasih juga pada warga Kebalen Wetan Gang Mawar RT 09 RW 04 atas penerimaannya yang pada kami sehingga tercipta lingkungan yang mendukung dalam setiap pelaksanaan kegiatan KSM. Terima kasih yang terakhir dan tak kalah penting pada adik-adik atas kerjasamanya selama kegiatan KSM sehingga semua kegiatan berjalan lancar.

\section{DAFTAR RUJUKAN}

Desmita. (2010). Perkembangan Peserta Didik. In Universitas Nusantara PGRI Kediri.

Dewi, P. Y. A. (2019). Gerakan Membaca Di Awal Pelajaran Guna Membangun Budaya Literasi Di Sekolah Dasar. Prosiding Seminar Nasional Pendidikan Dasar (Senada IV), 77-85. http://jayapanguspress.penerbit.org/index.php/PN/article/view/249

Hidayah, L. (2017). Implementasi Budaya Literasi di Sekolah Dasar Melalui Optimalisasi Perpustakaan: Studi Kasus di Sekolah Dasar Negeri di Surabaya. JU-Ke Uurnal Ketahanan Pangan), 1(2), 48-58.

Kurniasih, Rahmati, N. A., Umamah, A., \& Widowati, D. R. (2019). English Conversation Class 
(ECC) Untuk Menciptakan English Environment Di SMA Islam Nusantara (SMAINUS). Jurnal Inovasi Hasil Pengabdian Masyarakat (JIPEMAS), 2(2), 161-169. https://doi.org/10.33474/jipemas.v2i2.2571

Masdudi. (2015). Karakteristik Perkembangan Pendidikan Anak Usia Dini. AWLADY : Jurnal Pendidikan Anak.

Ojose, B. (2008). Applying Piaget's Theory of Cognitive Development to Mathematics Instruction. The Matematics Educator, 18(1), 26-30. https://files.eric.ed.gov/fulltext/EJ841568.pdf

Permendikbud no 23 tahun 2015. (2017). Membangun Budaya Membaca Pada Anak Melalui Program Gerakan Literasi Sekolah. Jurnal Pendidikan Dan Pembelajaran Dasar.

Rahmawati, A., \& Tutiasri, R. P. (2021). Edukasi bermain online games secara sehat pada anak-anak usia sekolah dasar. Jurnal Inovasi Hasil Pengabdian Masyarakat (JIPEMAS), 4(1), 69-77. https://doi.org/10.33474/jipemas.v4i1.7841

Uce, L. (2015). The golden age: Masa Efektif Merancang Kualitas Anak. Jurnal Pendidikan Anak Bunayya, 1(2), 77-92. raniry.ac.id/index.php/bunayya/article/view/1322 